\title{
An Exploratory Study: How Vocabulary Instruction Influences Writing Fluency
}

\section{Wakako Takinami \\ Tottori University}

\section{Reference Data:}

Takinami, W. (2020). An exploratory study: How vocabulary instruction influences writing fluency. In P. Clements, A. Krause, \& R. Gentry (Eds.), Teacher efficacy, learner agency. Tokyo: JALT. https://doi.org/10.37546/JALTPCP2019-55

In this research I investigated how vocabulary presentation in explicit vocabulary instruction influenced EFL students' writing fluency and controlled productive ability. Vocabulary instruction, 10-minute freewriting, and vocabulary pre- and post-tests were given to Japanese university students. ANOVA and Pearson's product-moment correlation coefficient were used to analyze test scores as well as the number of words, including the number of target words in the students' compositions. I found students wrote more fluently when target words were presented in sentences than when presented alone. I also found explicit vocabulary instruction helped students improve their controlled productive ability no matter whether the vocabulary was presented as words alone, in collocations, or in sentences. This paper concludes with suggestions concerning vocabulary instruction and possible future studies.

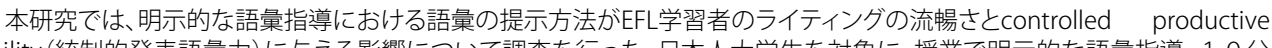

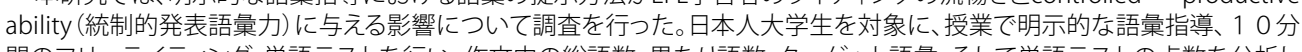

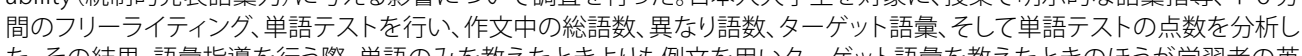

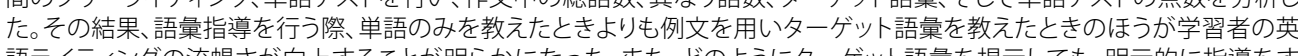

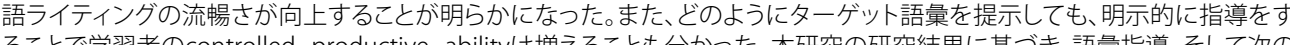
研究テーマに関する示唆が提示されている。

his is follow-up to a replication study conducted by Takinami (2018), which found that students saw their limited English vocabulary as a contributing factor for their difficulty in writing even after receiving vocabulary instruction on words from a textbook. The findings led to further questions about what vocabulary should be taught as well as how it should be taught to improve students' writing fluency. In this study, I focused on how vocabulary should be taught and investigated the influences of three different types of vocabulary instruction on writing fluency.

\section{Key Terms}

Two key terms used in this study are writing fluency and controlled productive ability. Writing fluency seems difficult to define. Writing fluency as well as accuracy and complexity have been frequently used in second language writing research to assess written production (e.g., Ellis \& Yuan, 2004; Plakans, Gebril \& Bilki, 2019; Wigglesworth \& Storch, 2009). However, as Abdel Latif (2012) found, writing fluency has been defined in various ways and different researchers assess it differently. Some researchers investigated the writing process, while others examined the end product. For this research, I referred to writing fluency as writing speed and looked at the total number of words (i.e., tokens) and the number of different words (i.e., word types) written within a set time. This is different to the measures which Abdel Latif (2012) recommended, but it was not feasible to video-record and observe each individual participants' composition process in class. Moreover, tokens seemed to be one of the most frequently used measures to assess writing fluency (e.g., tokens and word frequency levels in Fellner and Apple (2006), tokens in Kinshi (2009), tokens, the number of sentences, and words per sentence in Nguyen (2015)).

Controlled productive ability is defined in Laufer and Nation (1999) as

The ability to use a word when compelled to do so by a teacher or researcher, whether in an unconstrained context such as a sentence-writing task, or in a constrained context such as a fill-in task where a sentence context is provided and the missing target word has to be supplied. (p. 37)

To assess this type of productive knowledge, I used vocabulary tests modelled on the Productive Vocabulary Levels Test (Laufer \& Nation, 1999), and analyzed whether or 
not participants had successfully learned to use the target words. Some might argue that such tests do not measure "real" productive knowledge because the tests do not allow test takers free production. However, referring to aspects of vocabulary knowledge and use according to Nation (2013, pp. 48-50), it appeared reasonable to consider that participants had acquired a type of productive knowledge of target vocabulary if they were able to provide a word in the target language that would express a meaning given in their first language and spell the word correctly.

\section{Literature Review and Research Questions}

Vocabulary is essential for writing fluently, and vocabulary instruction plays an important role in students' vocabulary development. Many researchers investigated efficient and effective ways to teach vocabulary. For example, in the ESL context, Folse (2006) examined the effects of different types of exercises on vocabulary retention. In the EFL context, Nakata (2017) examined the influences of task repetition on vocabulary learning. A common finding was that explicit vocabulary instruction is just as important as implicit vocabulary instruction in helping students develop their vocabulary.

The effects of explicit vocabulary instruction on writing have also been investigated. For example, in the ESL context, Lee (2003) examined the influence of explicit instruction on the improvement in lexical quality in writing, and Colovic-Markovic (2017) examined the influence on the vocabulary students used in their writing. In the EFL context, Kinshi (2009) examined vocabulary instruction and writing fluency. All three researchers showed that explicit vocabulary instruction effectively helps students improve their writing.

However, more research is needed to better understand the effects of explicit vocabulary instruction on students' writing. One important topic is finding out which is more effective: explicit instruction of words, or explicit instruction of collocations. Lee (2003) examined explicit instruction of words and collocations, but she did not analyze them separately. Colovic-Markovic (2017) only examined explicit instruction of collocations.

Another topic which needs more research is to find out how explicit vocabulary instruction affects EFL writing. Kinshi (2009) reported an improvement in her students' writing fluency. However, she attributed the improvement to the fact that her research was conducted during writing lessons, and she did not report any influence of vocabulary instruction. Therefore, this research aimed to answer the following questions:
(1) When topic-related words are explicitly taught, what influence does the style of vocabulary instruction have on EFL students' writing fluency?

(2) When topic-related words are explicitly taught, what influence does the style of vocabulary instruction have on EFL students' controlled productive ability?

Methodology and Procedure

Participants

Participants were 81 Japanese first-year university students majoring in engineering. Their first language was Japanese, and their English proficiency level was between lower intermediate and intermediate.

Table 1. Participants

\begin{tabular}{lccc}
\hline & Group 1 & Group 2 & Group 3 \\
\hline Number of & 25 & 28 & 28 \\
Students & (Male 22, Female 3) & $($ Male 27, Female 1) & (Male 24, Female 4) \\
TOEIC & $\mathrm{M}=365.80$ & $\mathrm{M}=369.82$ & $\mathrm{M}=354.64$ \\
Score & $\mathrm{SD}=77.307$ & $\mathrm{SD}=81.269$ & $\mathrm{SD}=74.211$ \\
Target & Words & Collocations & Sentences \\
Vocabulary & & & \\
Instructor & Teacher K & Teacher T & Teacher T \\
\hline
\end{tabular}

As shown in Table 1, students were divided into three groups. When an ANOVA was performed to compare the mean TOEIC scores of the three groups, no statistically significant results were obtained $(\mathrm{F}(2,78)=0.286, \mathrm{MSe}=6031.468, \mathrm{p}=0.752>.05)$. This indicates there was no significant difference in English proficiency among the groups.

The target vocabulary was presented differently to each group: as words alone to Group 1, in collocations to Group 2, and in sentences to Group 3. Students were taught by Japanese instructors who speak Japanese as their first language. All instructions and explanations in class were given in English.

There were originally 27 students in Group 1, but two students, who spoke Chinese as their first language, were removed from the final data to make a more homogeneous group. There were originally 30 students in Group 2 and 29 in Group 3. However, two 
students needed to be removed from Group 2 and one student had to be removed from Group 3 because they missed two of the three lessons when data was collected.

\section{Target Words}

Thirty-nine target words were chosen from student compositions collected during the previous replication study (Takinami, 2018) as well as from the course textbook. (See Appendix A for full lists.) In order to choose target words, all the word types, the number of occurrences, and frequently appearing phrases were obtained from the compositions, using free online software, "Text Analyzer" (https://www.online-utility.org/text/analyzer. jsp). Then, vocabulary in the coursebook and the subtopics and details provided in the compositions and textbook were carefully reviewed. The same process was repeated to decide collocations and sentences in which the target words would be presented as well as sentences that would appear in pre- and post- vocabulary tests. (See Appendices B and $\mathrm{C}$ for full lists of collocations and sentences used in the vocabulary instruction.) All the words, collocations, and sentences were chosen with the aim of helping students write about the assigned topics.

When selecting target words, not only the number of occurrences but also spelling was taken into consideration. Examples of words that many students had spelled incorrectly were castle, climb, exercise, license, and salary. Almost all the target words appear in secondary school textbooks. According to the Genius English-Japanese Dictionary, located, merge, crab, overtime, and disadvantage are at the university level. Although all the individual words appear in secondary school textbooks, some students might have been unfamiliar with the words, hot spring and master's degree. Most of the target words were high frequency words, but reminding students of those words in relation to topics was still considered to be helpful in their writing.

\section{Research Design}

This research was conducted in compulsory English oral communication classes. As the course name suggests, it is not a writing course but rather aims to help students develop their English communication skills. Data was collected three times, the first being the pilot study. The data was always collected in the same way and all three groups followed the procedure shown in Table 2 .
Table 2. Procedure

\begin{tabular}{|c|c|}
\hline Week 1 & Week 2 \\
\hline [Beginning of a unit] & - Explicit vocabulary instruction \\
\hline - Vocabulary pre-test & [Regular lesson using the textbook] \\
\hline \multirow{3}{*}{ [Regular lesson using the textbook] } & - Freewriting \\
\hline & - Vocabulary post-test \\
\hline & [End of the unit] \\
\hline
\end{tabular}

The explicit vocabulary instruction took 10 to 15 minutes. In the instruction, 13 target words were presented either as words alone, in collocations, or in sentences, accompanied by Japanese translation. Students first practiced the pronunciation. Then, they gave quizzes to their partners, giving the Japanese translation and asking for its English counterpart.

To answer the first research question ("What influence does the style of vocabulary instruction have on EFL students' writing fluency?"), freewriting activities were used. The topic was related to the textbook unit. The first topic was "Hometown," the second was "An Interesting Class," and the third was "An Interesting Job." Students wrote for 10 minutes. Although they were not given any time for planning, they had listened, read, and spoken about the topic in class beforehand. Instructions were given orally and in a written form on the freewriting worksheet. Their freewriting was collected, but no feedback was given.

To answer the second research question ("What influence does the style of vocabulary instruction have on EFL students' controlled productive ability?”), pre- and postvocabulary tests were used. These tests contained the same sentences but in a different order. Also, the first letter was provided for each word to limit students answering with non-target words. (See Appendix D for all the pre-tests and Appendix E for the post-test used in the first data collection.) The tests were conducted primarily to find if students were able to write the target words, with correct spelling, that would express Japanese meanings. Therefore, I tried to avoid giving them context clues by using collocations and sentences which were different to those used for vocabulary instruction. Students were 
given five minutes to answer 13 fill-in-the-blank questions. Each time, students were reminded that the results of the test would not be used for assessment purposes.

\section{Data Analysis Method}

To answer the first research question about the influence that the style of vocabulary instruction has on students' writing fluency, their handwritten compositions were first typed on a computer. Then, tokens and word types were counted, using Text Analyzer. Next, the compositions were manually checked to exclude Japanese words, written in Romaji, that would not be known by readers unfamiliar with Japanese (e.g. konchu for insects, and jishin for earthquakes). Also excluded were misspelt words which would be difficult for non-Japanese speakers to guess the meaning of (e.g. riterasier for literature, and futer for future). Misspelt words that had sufficient clues to guess the correct meaning (e.g. mathmatics for mathematics, and pronounciation for pronunciation) were included in the analysis, as were words which had problems with inflectional morphology (e.g. classical musics for classical music, and studyed for studied). Lastly, the total number of target words (i.e., target tokens) and the number of different target words (i.e., target word types) in the compositions were manually counted. The number of times students had used the collocations or sentences that had been taught in class was also counted.

For the data analysis of research question one, an ANOVA was performed to compare the differences in tokens and word types between the three groups. A Pearson's product-moment correlation coefficient was also used to find if there was a correlation between the tokens, the word types, the target tokens, and the target word types in the compositions.

To answer the second research question about the influence that the style of vocabulary instruction has on students' controlled productive ability, each vocabulary test was scored out of 13 points. One point was given for each correct target word with the correct spelling. Then, for the data analysis, an ANOVA was performed to compare the gain in scores between the pre- and post-tests.

\section{Results}

Freewriting and Writing Fluency

Table 3 shows each group's mean total number of words plus the number of different words in the compositions.
Table 3. Mean Total Number of Words and the Number of Different Words

\begin{tabular}{ccccccc}
\hline & \multicolumn{2}{c}{ 2nd Data Collection } & \multicolumn{2}{c}{ 3rd Data Collection } \\
\cline { 2 - 7 } & $\mathrm{N}$ & $\begin{array}{c}\text { Total } \\
\text { Words }\end{array}$ & $\begin{array}{c}\text { Different } \\
\text { Words }\end{array}$ & $\mathrm{N}$ & $\begin{array}{c}\text { Total } \\
\text { Words }\end{array}$ & $\begin{array}{c}\text { Different } \\
\text { Words }\end{array}$ \\
\hline Group 1 & 21 & $\mathrm{M}=67.48$ & $\mathrm{M}=40.67$ & 24 & $\mathrm{M}=66.25$ & $\mathrm{M}=40.17$ \\
& & $\mathrm{SD}=22.47$ & $\mathrm{SD}=10.96$ & & $\mathrm{SD}=17.66$ & $\mathrm{SD}=10.71$ \\
Group 2 & 27 & $\mathrm{M}=77.96$ & $\mathrm{M}=44.78$ & 26 & $\mathrm{M}=95.92$ & $\mathrm{M}=58.46$ \\
& & $\mathrm{SD}=25.93$ & $\mathrm{SD}=11.70$ & & $\mathrm{SD}=20.00$ & $\mathrm{SD}=8.96$ \\
Group 3 & 27 & $\mathrm{M}=95.56$ & $\mathrm{M}=52.59$ & 28 & $\mathrm{M}=104.00$ & $\mathrm{M}=60.32$ \\
& & $\mathrm{SD}=32.20$ & $\mathrm{SD}=13.81$ & & $\mathrm{SD}=30.46$ & $\mathrm{SD}=13.04$ \\
\hline
\end{tabular}

Note. The first data collection was for a pilot study.

Statistically significant results were obtained when the three groups were compared using ANOVA. In the second data collection, the total number of words written by Group 3 was significantly larger than Group $1(\mathrm{~F}(2,72)=6.470, \mathrm{MSe}=757.373, \mathrm{p}=0.003<$

.05). Furthermore, the number of different words written by Group 3 was significantly larger than Group $1(\mathrm{~F}(2,72)=5.925, \mathrm{MSe}=151.609, \mathrm{p}=0.004<.05)$. In the third data collection, the number of different words written by Groups 2 and 3 was significantly larger than Group $1(\mathrm{~F}(2,75)=25.212, \mathrm{MSe}=123.145, \mathrm{p}=0.000<.05)$.

Regarding the total number of words in the compositions written for the third data collection, a Kruskal-Wallis test was performed instead of an ANOVA because the assumption of the homogeneity of variances was not met among the three groups. The result showed that the total number of words in the compositions was significantly affected by the difference in the way the vocabulary was presented $(\mathrm{H}(2)=25.210, \mathrm{p}=$ $0.000<.05)$. Mann-Whitney tests were administered to follow this up. The total number of words written by both Group $2(\mathrm{U}=77.500, \mathrm{r}=-.64)$ and Group $3(\mathrm{U}=108.500, \mathrm{r}=$ -.58) was significantly larger than Group 1.

In both data collections, there was no significant difference in the total number of words and the number of different words in the compositions written by Groups 2 and 3 . These indicate that the difference in the vocabulary presentation significantly influenced EFL students' writing fluency and they wrote more fluently when the target vocabulary was presented in sentences than when presented as words alone. 


\section{Vocabulary Tests and Controlled Productive Ability}

Table 4 shows each group's mean score for the vocabulary tests.

Table 4. Mean Score for the Vocabulary Tests

\begin{tabular}{lcccccc}
\hline & \multicolumn{3}{c}{ 2nd Data Collection } & \multicolumn{3}{c}{ 3rd Data Collection } \\
\cline { 2 - 6 } & $\mathrm{N}$ & Pre-test & Post-test & $\mathrm{N}$ & Pre-test & Post-test \\
\hline Group 1 & 24 & $\mathrm{M}=5.67$ & $\mathrm{M}=8.92$ & 25 & $\mathrm{M}=6.32$ & $\mathrm{M}=11.12$ \\
& & $\mathrm{SD}=2.55$ & $\mathrm{SD}=2.48$ & & $\mathrm{SD}=2.32$ & $\mathrm{SD}=1.94$ \\
Group 2 & 27 & $\mathrm{M}=4.33$ & $\mathrm{M}=9.15$ & 27 & $\mathrm{M}=5.19$ & $\mathrm{M}=10.93$ \\
& & $\mathrm{SD}=2.02$ & $\mathrm{SD}=1.94$ & & $\mathrm{SD}=2.34$ & $\mathrm{SD}=1.49$ \\
Group 3 & 24 & $\mathrm{M}=4.17$ & $\mathrm{M}=8.71$ & \multirow{2}{*}{28} & $\mathrm{M}=6.07$ & $\mathrm{M}=10.68$ \\
& & $\mathrm{SD}=2.39$ & $\mathrm{SD}=2.69$ & & $\mathrm{SD}=1.90$ & $\mathrm{SD}=1.72$ \\
\hline
\end{tabular}

Note. The first data collection was for a pilot study.

An ANOVA was performed to compare the pre- and post-test scores as well as the gain among the groups. Statistically significant results were obtained in the comparison between the pre- and post-test scores both in the second data collection $(\mathrm{F}(1.000,72.000)=329.463, \mathrm{MSe}=2.004, \mathrm{p}=0.000<.01:$ using the GreenhouseGeisser correction $)$ and the third data collection $(\mathrm{F}(1.000,77.000)=461.071, \mathrm{MSe}=$ $2.207, \mathrm{p}=0.000<.01)$. With the Bonferroni method, the mean scores of the post-tests were significantly higher than the pre-tests in every group. Importantly, there was no significant difference in the gain in the test scores among the three groups. These results indicate that the difference in the vocabulary presentation did not have a significant influence on the students' controlled productive ability. Explicit vocabulary instruction helped them develop their controlled productive ability no matter how the vocabulary was presented.

\section{Discussion}

Regarding students' writing fluency, a possible reason for the differences among the groups in the third data collection is that students in Groups 2 and 3 used more target words in their compositions than Group 1. When the tokens, the word types, the target tokens, and the target word types in the texts of all the students were analyzed, using Pearson's product-moment correlation coefficient, the tokens and the target tokens were significantly correlated with each other $(\mathrm{r}=0.400, \mathrm{p}=0.000<.01)$, so were the word types and the target word types $(\mathrm{r}=0.507, \mathrm{p}=0.000<.01)$. In addition, the tokens and the target word types were significantly correlated with each other $(r=0.416, p=0.000$ $<.01)$, as were the word types and the target tokens $(\mathrm{r}=0.438, \mathrm{p}=0.000<.01)$. These indicate that students who used more target vocabulary wrote more fluently. Figure 1 shows the tokens and the target tokens in the texts of all the students. As shown in the figure, the total number of words written by Groups 2 and 3 was larger than Group 1, and more target words appeared in the compositions written by Groups 2 and 3 than Group 1.

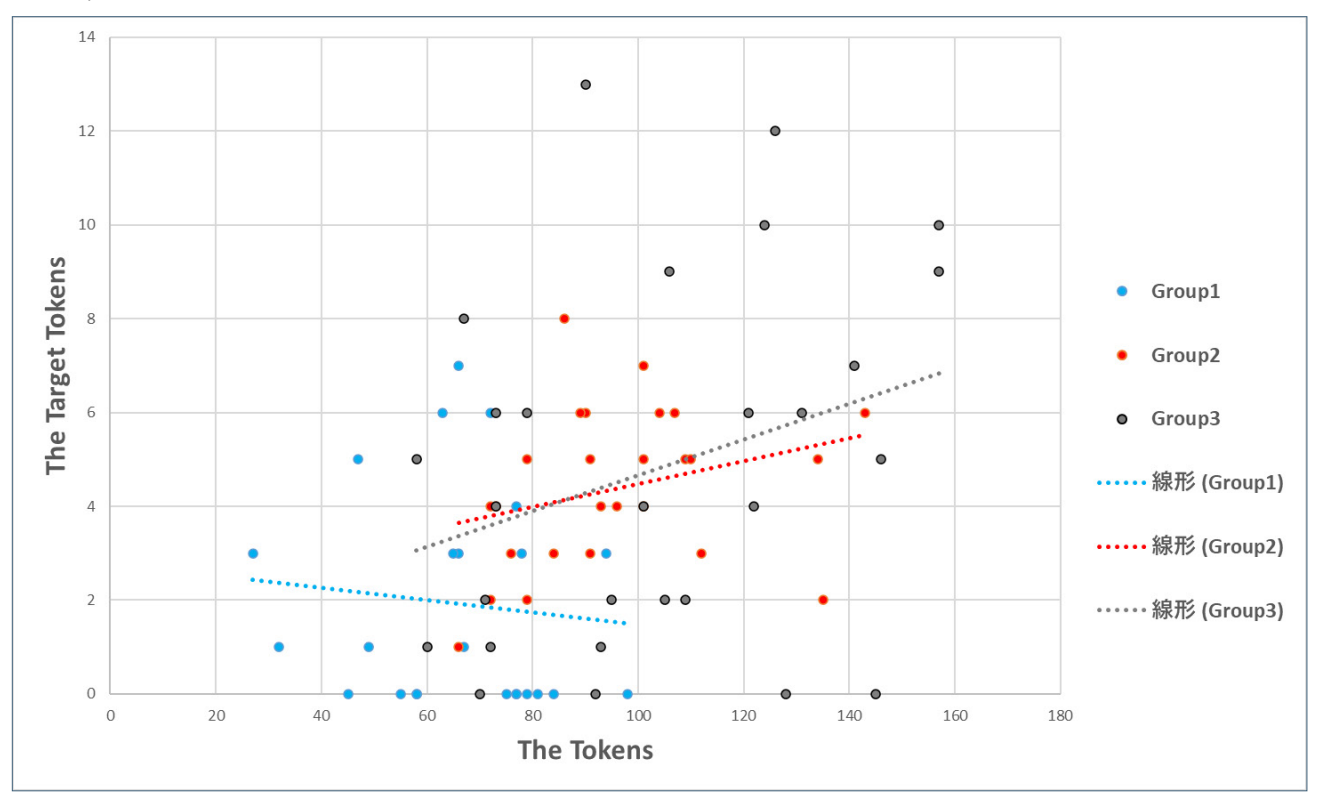

Figure 1. Number of tokens versus target tokens.

Note. The blue dotted line is for Group 1, the red for Group 2, and the gray for Group 3.

Figure 2 shows the word types and the target word types in the texts of all the students. As shown in the figure, the number of different words written by Groups 2 and 3 was larger than Group 1, and a wider variety of target words appeared in the compositions written by Groups 2 and 3 than Group 1. 


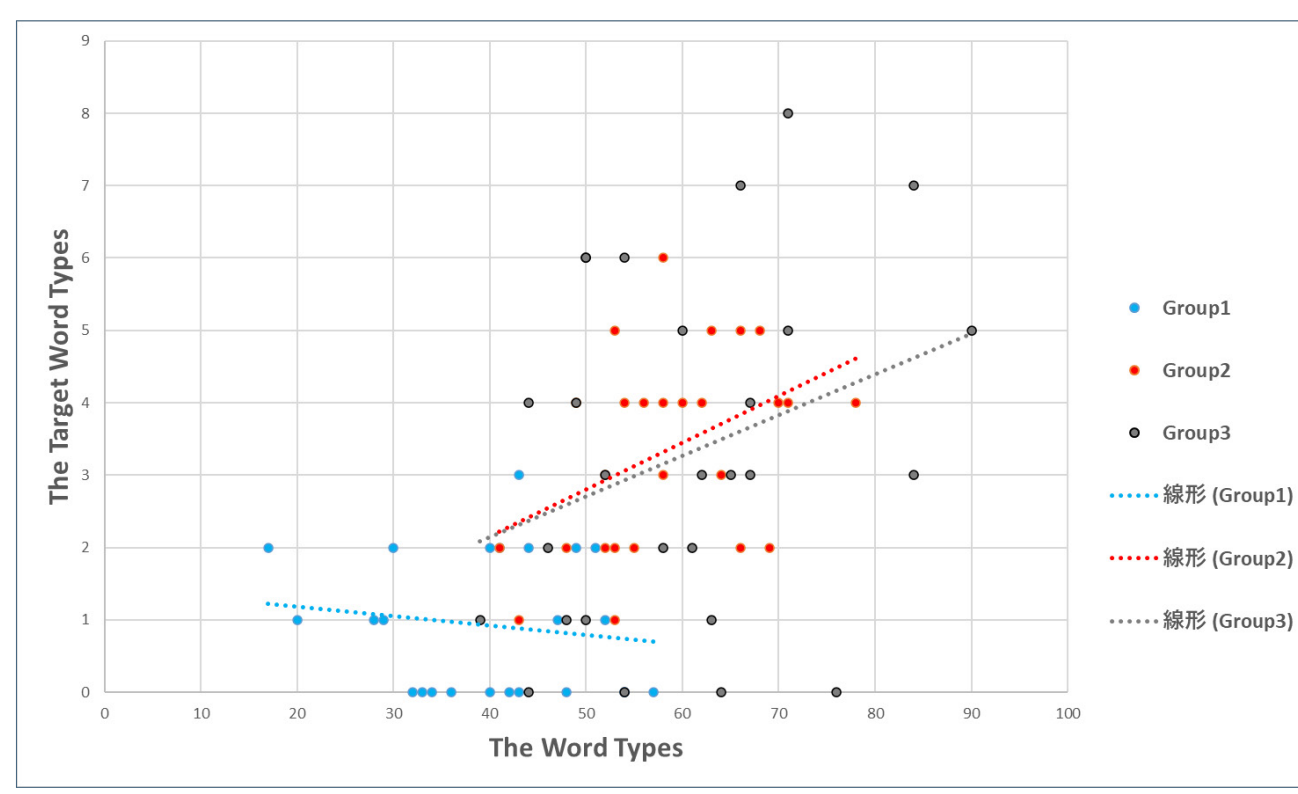

Figure 2. Number of word types versus target word types.

Note. The blue dotted line is for Group 1, the red for Group 2, and the gray for Group 3.

These indicate that students in Groups 2 and 3 used more target vocabulary in their compositions than Group 1.

Unlike in the third data collection, no statistical evidence was found to explain a reason for the difference between Groups 1 and 3 in the second data collection. However, a possible explanation could be that the more words students encountered in addition to target vocabulary while receiving vocabulary instruction, the more words they were able to use in their writing, which might have helped them to write longer texts. As shown in the following sample sentences written by students A from Group 1 and B from Group 3 with the target word, "period," student B used words from the model sentence. Note that students' sentences have not been edited for grammar or spelling errors.

Model sentence:

\section{Art class is in the first period}

Student A:

Phygical education class is Friday four periods.

Student B:

The class is in the first period on Thursday.
No statistical evidence was found to explain why there was no difference between Groups 2 and 3 in the second and third data collections. However, a possible explanation could be that, although some students in Group 3 used the model sentences as they were, many others only used part of them in their compositions. In the examples below, student $C$ used a model sentence as it was when using the target word, "license," in his sentence, while student D only used part of the model sentence (i.e., collocation) in her sentence.

Model sentence: We need to get a teacher's license to become a teacher. Student C: $\quad$ You need to get first class registered architect license to become first class registered architect.

Student D: Architects have to get a license.

In the second data collection, target vocabulary appeared 36 times in the compositions written by Group 3. It was seen eight times (22.2\%) in sentences that were similar to or almost the same as the model sentences, five times (13.9\%) in collocations, and 23 times $(63.9 \%)$ as words alone. Whereas, in the third data collection, target vocabulary appeared 135 times in the compositions written by this group. It was seen 54 times $(40 \%)$ in sentences that were similar to or almost the same as the model sentences, 24 times $(17.8 \%)$ in collocations, and 57 times $(42.2 \%)$ as words alone. It seemed that many students used target words either as words alone or in collocation even though the words were taught in sentences.

Regarding students' controlled productive ability, a possible explanation for improvement regardless of how the vocabulary was presented could be that only a short-term effect was examined in this research. Another explanation could be there was minimal difference in the amount of exposure to the target words. Not only Group 1 but also Groups 2 and 3 were aware which words were the target vocabulary because the target words were in bold type in the collocations and sentences. With close attention to the target words, students did exactly the same activities and tasks in class.

This research would suggest that, in order to help improve writing fluency, explicit vocabulary instruction should be given and target words should be taught in sentences but also in a way that allows students to pay attention to the target words as words alone and in collocations, as shown in the following example: "We need to get a teacher's license to become a teacher." 


\section{Conclusion}

\section{Overview of Findings}

The principal focus of this research was how vocabulary should be taught to improve students' writing, and I examined the influences of different types of vocabulary instruction on students' writing fluency. After analyzing their freewriting and vocabulary tests, I found that students wrote more fluently when the target words were presented in sentences than when presented alone. This is partly because they used target vocabulary more frequently and a wider variety of target words appeared in their compositions when the words were presented in sentences. Furthermore, the encounter with more words, in addition to the target vocabulary, during vocabulary instruction probably allowed the students to use more words in their writing.

I also found that explicit vocabulary instruction helped students develop their controlled productive ability no matter how the target vocabulary was presented. This is because only the short-term effects of the instruction were examined, and there was minimal difference in the amount of exposure to the target words among the three groups.

\section{Limitations of the Present Study and Suggestions for Further Research}

This research focused on how vocabulary instruction influenced students' writing fluency and used the number of words in their compositions to evaluate this influence. In future research, however, the use of additional measures such as the length of sentences and word frequency levels might help assess writing fluency more precisely. Furthermore, not only quantitative but also qualitative aspects of writing should be examined. Accuracy in target vocabulary use in writing and its contribution to the overall quality of compositions could be investigated.

Regarding target vocabulary, choosing the target words for this research was difficult due to the vagueness of the topics in the textbook. Therefore, clearer topics should be chosen for future research. Different ways of selecting target vocabulary might also be needed. As for research design, only short-term effects of vocabulary instruction were examined in this research. Hence, long-term effects should also be examined in future research. Four weeks seem to be the longest interval between vocabulary instruction and a delayed test (Nakata, 2017), so it might be useful to look at a longer interval such as two months. In addition, future research could take efficiency of the instruction into consideration to further evaluate the effectiveness of the instruction. Lastly, two teachers were involved with the vocabulary instruction for this research. As stated earlier, each time the data was collected in the same way and all three groups followed the same procedure. Both teachers used the same textbook and did the same activities and tasks in class. However, the way they did the activities and tasks might have affected the research results. Therefore, it is ideal if the same teacher can give instruction to all groups in future research.

\section{Acknowledgements}

I would like to express my deep gratitude to Masahiro Kobayashi. Without his expert advice and gentle support, my research would have had many setbacks. I am also indebted to Shirley Leane. The two of them provided encouragement and suggestions with the writing of this paper. Their support enabled me to give my very first academic presentation and publish my very first research paper. Thank you.

\section{Bio Data}

Wakako Takinami is an Assistant Professor at Tottori University. Her research interests include second language writing and vocabulary instruction.<w.takinami@tottori-u. ac.jp>

\section{References}

Abdel Latif, M. M. (2012). What do we mean by writing fluency and how can it be validly measured? Applied Linguistics, 34(1), 99-105. doi.org/10.1093/applin/ams073

Colovic-Markovic, J. (2017). “I used them because I had to...”: The effects of explicit instruction of topic-induced word combinations on ESL writers. TESOL International Journal, 12(1), 32-47.

Ellis, R. \& Yuan, F. Y. (2004). The effects of planning on fluency, complexity, and accuracy in second language narrative writing. Studies in Second Language Acquisition, 26(1), 59-84. doi.org/10.1017/ S0272263104026130

Fellner, T. \& Apple, M. (2006). Developing writing fluency and lexical complexity with blogs. The JALT CALL Journal, 2(1), 15-26.

Folse, K. S. (2006). The effect of type of written exercise on L2 vocabulary retention. TESOL Quarterly, 40(2), 273-293. doi.org/10.2307/40264523

Kinshi, K. (2009). Bringing vocabulary practice into active use: Towards motivated learning. The Bulletin of the Writing Research Group, JACET Kansai Chapter, 8, 15-26.

Laufer, B. \& Nation, P. (1999). A vocabulary-size test of controlled productive ability. Language Testing, 16(1), 33-51. doi.org/10.1177/026553229901600103 
Lee, S. H. (2003). ESL learners' vocabulary use in writing and the effects of explicit vocabulary instruction. System, 31(4), 537-561. doi.org/10.1016/j.system.2003.02.004

Nakata, T. (2017). Does repeated practice make perfect? The effects of within-session repeated retrieval on second language vocabulary learning. Studies in Second Language Acquisition, 39(4), 653-679. doi.org/10.1017/S0272263116000280

Nation, I. S. P. (2013). Learning vocabulary in another language ( $2^{\text {nd }}$ ed.). Cambridge, United Kingdom: Cambridge University Press.

Nguyen, T. C. L. (2015) Written fluency improvement in a foreign language. TESOL Journal, 6(4), 707-730. doi.org/10.1002/tesj.186

Plakans, L., Gebril, A., \& Bilki, Z. (2019). Shaping a score: Complexity, accuracy, and fluency in integrated writing performances. Language Testing, 36(2), 161-179. doi. org $/ 10.1177 / 0265532216669537$

Takinami, W. (2018). Influences of topic selection methods on L2 learners' writing fluency: Replication study. Tottori University Education Centre Bulletin, 14, 63-78.

Wigglesworth, G. \& Storch, N. (2009). Pair versus individual writing: Effects on fluency, complexity and accuracy. Language Testing, 26(3), 445-466. doi.org/10.1177/0265532209104670

\section{Appendix A \\ Target Vocabulary Words}

\section{First Data Collection}

population, located, agricultural, commercial, merge, crab, pear, delicious, castle, shrine, hot spring, skiing, climb

\section{Second Data Collection}

opinion, period, improve, opportunity, pronunciation, perspective, logically, in detail, solve, experiment, knowledge, report, exercise

\section{Third Data Collection}

architect, engineer, design, robot, earn, license, pass, advantage, salary, overtime, disadvantage, repair, master's degree

\section{Appendix B \\ Collocations with Target Vocabulary Words}

\section{First Data Collection}

a population of, be located in, an agricultural city, a commercial city, merge into, Matsuba crab, $20^{\text {th }}$ Century pear, taste delicious, Himeji castle, Meiji shrine, an old hot spring, go skiing, climb a mountain

\section{Second Data Collection}

express an opinion, in the first period, improve English communication skills, an opportunity to speak in English, practice pronunciation, a new perspective, think logically, learn in detail, solve a math question, do an experiment, up-to-date knowledge, write a report, exercise regularly

\section{Third Data Collection}

a first-class registered architect, a mechanical engineer, design a church, build a robot, earn about 250,000 yen, a teacher's license, pass an examination, the advantage of working as a pilot, a high salary, do overtime, the biggest disadvantage, repair a home, do a master's degree

\section{Appendix C}

\section{Sentences with Target Vocabulary Words}

\section{First Data Collection}

Cairo has a population of 8 million people.

Tottori city is located in the northeast of Tottori prefecture.

Tottori is a small agricultural city.

Yonago city is a commercial city in the northwest of Tottori prefecture.

Yazu merged into Tottori city in 2004.

Tottori city is famous for Matsuba crab.

$20^{\text {th }}$ Century pears taste sweet. 
Oysters from Hiroshima prefecture taste delicious.

You can see beautiful cherry blossoms around Himeji castle in spring.

A lot of people visit Meiji shrine on New Year's Day.

Dogo Onsen is one of the oldest hot springs in Japan.

I go skiing on Mt. Daisen every winter.

Every year a lot of foreign tourists climb Mt. Fuji.

\section{Second Data Collection}

I always feel nervous when I express an opinion in front of my classmates.

Art class is in the first period.

We can improve English communication skills through many different activities.

In Communication English A class, we have a lot of opportunities to speak in English.

In Chinese class, we practice pronunciation at the beginning of every lesson.

His lectures provide us with new perspectives.

Philosophy classes help me to enhance my capability to think logically.

We learned about the Edo Period in detail in her Japanese History class.

I feel satisfied when I can solve a difficult math problem.

We did an experiment in groups of four in Chemistry class.

We get up-to-date knowledge in his Chemistry class.

We have to write a report for a Physics class every week.

Thanks to Physical Education classes, I can exercise regularly.

\section{Third Data Collection}

I would like to become a first-class registered architect in the future.

A mechanical engineer builds many different things such as cars, airplanes, and ships.

He designed a church and built it with paper tubes.

My dream is to build a robot that helps elderly people.

An aircraft mechanic earns about 250,000 yen a month.

We need to get a teacher's license to become a teacher.

We have to pass an examination to become a civil servant.
The advantage of working as a pilot is that you can visit a lot of places.

A good point of this job is a high salary.

Teachers often have to do overtime.

The biggest disadvantage of this job is long working hours.

I want to repair my parents' old home in my hometown.

I am planning to do a master's degree at Kobe University.

\section{Appendix D}

Pre-tests

First Data Collection

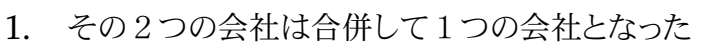

The two companies ( $\mathrm{m}$ ) into one.

2. よく切れるナイフを使ってリンゴと梨の皮をむきなさい Use a sharp knife and peel the apples and ( $\mathrm{p}$ ).

3. そのスイカはとてもおいしかった The watermelons tasted (d ).

4. この温泉は腰痛に効くと言われている This (h ) (s ) is said to help cure backache.

5. 島根には出雲大社という有名な神社がある Shimane has a famous (s ) called lzumo Taisha.

6. エドモンド・ヒラリーはエベレストに登った最初の人だった Edmund Hillary was the first man to (c ) Mount Everest.

7. 私の故郷では小学生は体育の授業でスキーの仕方を習う In my hometown, elementary school students learn how to (s ) in P.E. class.

8. カイロはエジプト北部のナイル川沿いに位置している Cairo is (l ) in the north of Egypt on the Nile River.

9. 大阪は日本で最初の商業都市だ Osaka is the first (c ) city in Japan.

10. リオデジャネイロは人口 900 万人のとても大きな街である Rio de Janeiro is a very large city with a (p ) of 9 million people. 
11. 鳥取県と同じように、福井県は越前ガニで知られている

Similar to Tottori prefecture, Fukui prefecture is known for Echizen (c ).

12. 日本では城を造るのに多くの石や岩が用いられた

Many stones and rocks were used to build (c ) in Japan.

13. 岡山の有名な農産物には桃とブドウがある

Famous (a ) products from Okayama include peaches and grapes.

\section{Second Data Collection}

1. 理論的に考える能力を高めたかったので、この講座を受けることにしました I decided to take this course because I wanted to develop my ability to think (l ).

2. 彼女の意見はみんなを驚かせた

Her (o ) surprised everyone.

3. その実験は失敗した

The (e ) failed.

4. あなたの考えを詳しく説明していただけませんか

Could you please explain your own idea (i ) (d )?

5. 他の言語学習者と勉強するのは言語技能を高めるのに役に立つ

Studying with other language learners helps to (i ) language skills.

6. 体を鍛えて健康でいるために、私は毎日運動しています

I (e ) daily in order to get fit and remain healthy.

7.このような機会は二度と訪れないだろう An (o ) like this will never come again.

8. スペイン語の発音は英語をしゃべる人にはかなり簡単だ The (p ) of Spanish is fairly easy for English speakers.

9. あなたは水曜日までにそのレポートを提出しなければならない You are required to turn in that $(\mathrm{r}$ ) by Wednesday.

10. 小さい子供だってこんな問題は解けるよ Even a young child can (s ) this problem.

11. 彼の歴史の知識はガイドとして働くのには不十分だ He doesn't have enough ( $\mathrm{k}$ ) of history to work as a guide.

12. 私はその状況について少し違った見方をした

I got a slightly different ( $\mathrm{p}$ ) on the situation.
13. 生物学の授業は月曜日の 3 時限めにある Biology class is on Monday $3^{\text {rd }}(\mathrm{p} \quad$ ).

Third Data Collection

1. サイズが大きいのが明らかに不利な点だ Its large size is an obvious (d ).

2. どれだけ残業をしなくてはならないのですか How much (o ) do you have to do?

3. 彼女はその試験に容易に合格した She easily (p )ed the exam.

4. 皿洗いをして時給 580 円かせぐ I (e ) 580 yen an hour washing dishes.

5. この新しい機械を用いることの利点を説明したいのですが

I would like to explain the (a )s of using this new machine.

6. 給料は数年ごとに自動的に上がる

The (s ) goes up automatically every few years.

7. 運転免許証の期限が切れた My driver's (l ) has expired.

8.そのスタジアムは主に野球をするために設計された The stadium was primarily (d )ed for baseball

9. 製造業者はそれを無料で修理した The manufacturer ( $\mathrm{r}$ )ed it without charge.

10.ロボットの使用は急速に増えている The use of $(\mathrm{r}) \mathrm{s}$ is increasing rapidly.

11. この講座は航空宇宙学の技術者を養成するためのものだ This is a training course for aerospace (e s.

12. プロの建築家がこの図面を作成した A professional (a ) drew up the plans.

13. 鳥取大学から土木工学で修士号を得た

I got a (m ) (d ) in Civil Engineering from Tottori University. 


\section{Appendix E}

Post-test for First Data Collection

1. 私の故郷では小学生は体育の授業でスキーの仕方を習う

In my hometown, elementary school students learn how to (s ) in P.E. class.

2. 岡山の有名な農産物には桃とブドウがある

Famous (a ) products from Okayama include peaches and grapes.

3. 大阪は日本で最初の商業都市だ

Osaka is the first (c ) city in Japan.

4. リオデジャネイロは人口 900 万人のとても大きな街である

Rio de Janeiro is a very large city with a (p ) of 9 million people.

5. この温泉は腰痛に効くと言われている

This (h ) (s ) is said to help cure backache.

6. そのスイカはとてもおいしかった

The watermelons tasted (d ).

7. エドモンド・ヒラリーはエベレストに登った最初の人だった

Edmund Hillary was the first man to (c ) Mount Everest.

8. 島根には出雲大社という有名な神社がある

Shimane has a famous (s ) called Izumo Taisha.

9. 鳥取県と同じように、福井県は越前ガニで知られている

Similar to Tottori prefecture, Fukui prefecture is known for Echizen (c ).

10. カイロはエジプト北部のナイル川沿いに位置している

Cairo is (l ) in the north of Egypt on the Nile River.

11. 日本では城を造るのに多くの石や岩が用いられた

Many stones and rocks were used to build (c ) in Japan.

12. よく切れるナイフを使ってリンゴと梨の皮をむきなさい

Use a sharp knife and peel the apples and $(\mathrm{p} \quad$ ).

13. その 2 つの会社は合併して1つの会社となった

The two companies (m ) into one. 